KNAPP ÉVA

\title{
Palingenius Zodiacus vitae-je a magyarországi Album Amicorumokban
}

The reception history of the Zodiacus vitae is an independent research topic long ago outside Hungary, researchers have been analyzing the various levels and forms of reception for decades. However, the peculiarities of the Palingenius-reception in Hungary have not been systematically studied. Although full edition of the entire Zodiacus vitae printed in Hungary is not known, several copies of different printed editions arrived to Hungary. The popularity of this epic philosophical poem is indicated by several entries in the autograph albums of peregrine students. These Hungarianrelated entries mostly accurately quote the details of the work in gnomes. The conscious, customized combination and re-functioning of quotations follows the international practice of the era. ${ }^{1}$

Marcellus Palingenius Stellatus itáliai humanista, a Zodiacus vitae ${ }^{2}$ címü, számos kiadást és fordítást megért, évszázadokon át Európa-szerte kedvelt tanköltemény (filozofikus poéma, eposz, „nagyeposz”) szerzője az európai irodalom történetének rejtélyes alakjai közé tartozik. Életrajzi adatai jelentős részben bizonytalanok, ${ }^{3}$ a személyére vonatkozó, biztos-

\footnotetext{
${ }^{1}$ A publikáció az MTA-SZTE Antikvitás és Reneszánsz: Források és Recepció Kutatócsoport (TK2016-126) támogatásával jelent meg. A téma folytatása (A Zodiacus vitae a magyarországi könyvtárakban címmel) várhatóan az A\&R III-ban jelenik meg.

${ }^{2}$ Kritikai kiadás: CHOMARAT (1996). A kiadást ZV rövidítéssel, római számos kötetjelzéssel és a verssorok számával hivatkozom.

${ }^{3}$ PALUMBO (2007: 294-298) Életét feltételesen 1500-1551 közé datálják, a legváltozatosabb variációkban. Vö. CERL Thesaurus. A „Stellatus” névelem alapján születési helyét több lexikon Ferrara tartomány Stellata településére helyezi. Másutt születési helyeként Nápolyt valószínűsítik.
} 
nak tekinthető tények nagyrészt magából a műből származnak. Alakjához különféle, jobbára legendás történetek kapcsolódnak.

Az összesen mintegy tízezer hexameter terjedelmü eposz első, megjelenési évet nem tartalmazó, feltételesen 1531-re datált velencei kiadásának piros betüs, ősnyomtatványokra emlékeztető címlapján a következő olvasható: Zodiacus vitae / pulcherrimum opus atque / utilissimum Marcelli / Palingenii Stellati Poeltae ad illustrissi/mum Ferrariae du/cem Herculem / secundum, / foelici/ter in/cipit. Azaz a költeményt a ferrarai Ercole II. d'Este (1508-1559) fejedelemnek ajánlotta a szerző. A kiadvány utolsó nyomtatott oldalán található a szintén ősnyomtatványokra jellemző „registrum" (szignatúra) és impresszum (Venetijs Bernardinus Vitalis Venetus impressit). A nyomdász, Bernardinus Vitalis életrajzi adatai a szerzőéhez hasonlóan bizonytalanok, velencei nyomdászi tevékenysége szakaszosan, 1494-1508, 1510-1511, 1517-1521 és 1523-1539 között adatolható.

Palingenius orvos volt, s X. Leó pápa idejében (1513-1521) Rómában élt. ${ }^{4}$ Az életére vonatkozó utolsó biztos adat végrendeletének 1537. október 26-iki keltezése Forliból. Egy XVI. századi vatikáni forrás szerint hitetlenként (nihil credens [...]) Krisztus istenségének tagadójaként ([...] neque divinitatem Christi) halt meg Cesenában. ${ }^{5}$ Giglio Gregorio Giraldi Dialogi duo de Poetis nostrorum temporum (1551) címü munkájában közölte azt az „olvasás”-ból merített adatot, mely szerint Palingenius földi maradványaival „,kegyetlenkedtek” (in eius cineres saevitum est) az őt ért impietas vádja miatt. ${ }^{6}$ Ezt többen úgy értelmezték, hogy csontjait halála után kihantolták, és megégették. Erre utalt például az első jezsuiták egyike, a bolognai Francesco Palmio, amikor Palingenius holttestének sorsáról tudósította a rend második generálisát, Diego Laynezt 1558 novemberében. ${ }^{7}$ Palingenius személyét utóbb Jacopo Facciolati (1682-

\footnotetext{
4 ZV XI, 846-851.

5 Marcellus Palingenius Stellatus nihil credens neque divinitatem Christi, Cesenae perfidus mortuus est. Kézirat, Biblioteca Apostolica Vaticana Vat. Lat. 6207, 232v.

6 GIRALDI (1551: 94-95): Legitur quoque Marcelli Palingenij Stellati liber hexametro versu conscriptus [...] post eius mortem in eius cineres saevitum est, ob impietatis crimen.

7 ,il suo cadavere fu dishumato et publicamente bruggiato", ld. BACCHELLI (1985a: 275292); BACCHELLI (1985b: 309-315); BACCHELLI (1999: 357-374).
} 
1769) azonosította - valószínúleg tévesen - Pier Angelo Manzoli (Manzolli)-val. ${ }^{8}$

A Zodiacus vitae az állatöv jegyei szerint tizenkét könyvre tagolt erkölcstani, morálfilozófiai poéma. A részben metafizikai-teológiai, részben tudományos szemléletű epikus „világtükör” (Weltspiegel) szerzője az emberi boldogság és a legfőbb jó (summum bonum) mibenlétét keresi. Foglalkozik - többek között - a valódi bölcsesség lépcsőfokaival, az élet optimális rendjével és a természetfilozófiával. A boldogság lényegének keresését összeköti tudományos ismeretekkel és metafizikai spekulációkkal, miközben szatirikus hangot üt meg - elsősorban az egyházi képmutatást illetően. Egy mondatban összegezve, a mű lényegében a kereszténység neoplatonikus átértelmezése az antikvitás ismeretében, az üdvtörténet mellőzésével. ${ }^{9}$ A verses argumentum szerint az első, bevezető könyv (Aries) után a második könyv (Taurus) a gazdagság, a harmadik (Gemini) az élvezetek, a negyedik (Cancer) Vénusz, az ötödik (Leo) a boldogság, a hatodik (Virgo) a halál és a nemesség témáját tárgyalja. A hetedik könyvben (Libra) az istenek és a lélek, a nyolcadikban (Scorpio) a sors hatalmának, a kilencedikben (Sagittarius) az ördög és az emberi szokások megismerésének, a tizedikben a bölcs ember (Capricornus), a tizenegyedikben (Aquarius) a természet, a tizenkettedikben (Pisces) a teremtett világ ősi alakjának kérdései állnak a középpontban.

A Zodiacus vitae szerzőjének fő célja az ember földi életének minél sokszínűbb bemutatása, különös tekintettel az erényekre és a kárhozatos cselekedetekre. Ezek alapos megismerése és mérlegelése révén Palingenius szerint az evilági sötétségből el lehet jutni a mennyig, azaz az Isten által teremtett világ ősi formájáig, s végül Istenig. A szerző állást foglalt kora több vitatott kérdésében, így például a lélekvándorlásról és az epikureizmusról értekezik. Élesen támadja, és válogatott kifejezésekkel, módszeresen szidalmazza a korabeli katolikus egyház képviselőinek bűneit (például kapzsiság, szexuális eltévelyedések), melyekről közvetlen tapasztalatot szerezhetett Rómában.

A költemény második kiadása 1537-ben Baselben került ki a sajtó alól Robert Winter nyomdájában, az első kiadástól részben eltérő, értel-

\footnotetext{
${ }^{8}$ FACCIOLATI (1765: 163-164, vö. még 173).

${ }^{9}$ KÜHLMANN (2016: 62-77).
} 
mezéssel kibővített címen: Zodiacus vitae, hoc est, de hominis vita, studio, ac moribus optime instituendis libri duodecim. A harmadik kiadás (Basel, Winter, 1543, VD 16 M853) a poéma tartalmával rokon keretszövegekkel (Johann Herold, Thomas Scauranus) ellátva és vele egybenyomtatott három, azonos címú munkával (Antonio Mancinelli, De quattuor virtutibus, VD 16 M503; Domenico Mancinelli, De quattuor virtutibus, VD 16 M529; De quattuor virtutibus, VD 16 Q34) együtt jelent meg. Az 1548-ban Nicolaus Brylinger bázeli nyomdájában készült újabb kiadás (VD 16 M854) alcíme először hívta fel a figyelmet arra, hogy a mü az oktatásban is használható: Opus mire eruditum, planeque Philosophicum. Diligentissime in usum studiosorum excusum. A 16. század közepétől egymás után jelentek meg újabb kiadásai, annak ellenére, hogy 1557-től folyamatosan megtalálható volt a tiltott könyvek jegyzékében (Index librorum prohibitorum). ${ }^{10}$ A 16. század végéig mintegy harminc, 1832-ig összesen közel ötven kiadása jelent meg Európában.

A recepciót elősegítette, hogy rétegzetten, a legkülönfélébb szinteken, eltérő módon és formákban lehetett értelmezni a szöveget. Így például az első német fordítás a német anyanyelvü világi olvasók széles rétegeinek szólt (Johann Spreng, Gürtel des Lebens, 1564), míg Caspar Barth Zodiacus vitae christianae, satyricon pleraque omnia verae sapientiae mysteria singulari suavitate enarrans címü, latin nyelvü átköltése (1623) az elit közönségnek készült. Eszerint német nyelvterületen viszonylag korán kialakult a mű két, eltérő tudásszintet feltételező befogadási közege. ${ }^{11}$ Amikor Mikołaj Rej (1505-1569) - a fordítók között szinte elsőként - lengyelre adaptálta (Wizerunk własny żywota człowyeka poczciwego, w ktorym iako we źwierciedle snadnie każdy swe sprawy oględać może, zebrany y s filozophow y z roznych obyczaiow swiata tego [...], W Krakowie, drukoea-

\footnotetext{
10 De BujAnda (1990: 602, nr. 700: Index de 1557 Roma 00166; Index de 1558 Louvain 162; 275-292). 1764-ben: Index (1764: 165). 1862-ben: Index (1862: 331).

11 További teljes terjedelmü német fordítások: Fr. Schisling, Thierkreis des Lebens (1785, $\left.{ }^{3} 1788\right)$, J. J. Pracht, Thierkreis des Lebens (I-IV, 1803-1815), M. A. Hug, Thierkreis des Lebens (1873). Fennmaradt az emlékezete Christoph Wirsung (1500-1571) tudományos igényű Zodiacus vitae-kommentárjának is. CHOMARAT (1996: Appendices, 506).
} 
no v Matysa Wirzbyęty, [post 7 VI] 1558), egy saját kora közép-keleteurópai igényei szerinti, humanista értelmezést készített. ${ }^{12}$

A Zodiacus vitae első megjelenése után gyorsan közkedveltté vált, elsősorban mint „tudáskompendium”. Kritikai szemlélete és kiemelkedő nyelvi eleganciája miatt nagyon sokan idézték és használták évszázadokon át, különféle kontextusokban, köztük olyan szerzők, mint Julius Caesar Scaliger és Giordano Bruno. Palingenius kortársa, Julius Caesar Scaliger a Poetices libri septem hatodik, Hypercriticus címü kötetében oldalakon át, részletekbe menően foglalkozott vele. Véleménye szerint: $P a$ lingenii poema totum Satyra est: sed sobria, non insana, non foeda. ${ }^{13}$ E sorok jelentős mértékben hozzájárultak a munka európai elterjedéséhez a poétikaoktatásban.

A Zodiacus vitaet a latin nyelv „mesteri” használata révén poétikairetorikai tankönyvként is használták; a 16. század második felétől különféle, módszeresen még számba nem vett, anonim Zodiacuskivonatok sora készült Európa-szerte. A mű hatástörténete Magyarországon kívül régóta külön kutatási téma, s aprólékos figyelemmel kísérik a recepció különféle szintjeit és formáit. A kutatásban elöl jár Anglia, ahol ugyancsak iskolai tankönyvként használták. Közismert, hogy Shakespeare a Zodiacus vitae ismeretében készítette az As You Like It címü komédiát és a Seven Age of Man címü lírai poémát.

Ezzel szemben a magyarországi Palingenius-recepció sajátosságait módszeresen még nem vizsgálták. A Zodiacus vitae kiadásokat a jelenkori könyvtárakban többnyire tankölteményként, vagy - a címből és nem a tartalomból következtetve - csillagászati munkaként (!) tartják számon. ${ }^{14}$ Kéziratos hagyatékának tanúsága szerint Bán Imre az 1970-es években figyelt fel a témára. A Zodiacus vitae 1789-es bázeli kiadásának a debreceni Egyetemi Könyvtárban őrzött példányából néhány oldalt ismeretlen céllal kézzel kimásolt, de kommentár nélkül hagyott. ${ }^{15}$ Balázs

12 Vö. LEPRI (2015: 67-93); OKOŃ (2014: 235-247, itt: 240). Vö. még, NAGYSOLYMOSI (1934: 15-16).

13 SCALigER (1607: 731-734).

14 Például a szegedi Somogyi Könyvtárban található két példány közül az 1754-ben megjelent hamburgi kiadást „asztrológia”, az 1832-es lipcsei kiadást viszont „latin irodalom tanköltemény 16. sz." tárgyszó alatt tartják számon. Letöltés: 2017. 02. 17. 15 SZÁrAZ (2010: I. nr. 131, a) Marcellus Palingenius Stellatus, 1976, 1977, 5). 
Péter Laczkovics János 1791-ben írott valláskritikai pamfletjeiröl ${ }^{16}$ értekezve bár a pamfletek mottói Palingenius-idézetek, s Balázs szerint Laczkovics a levelezésében is gyakran idéz a Zodiacus vitaeből - sommásan megjegyzi, hogy Palingenius „a 18. századi Magyarországon különös ismertségnek egyáltalán nem örvendo”” szerző. Többes számban szól „Palingenius írásai"'-ról, anélkül, hogy ezt a Zodiacus vitaen kívül más mü említésével indokolná. A tanulmány e részéhez tartozó két lábjegyzetben - konkrét adatra itt sem hivatkozva - előbbi megállapítását egyrészt azzal toldja meg, hogy Palingenius nevével „[...] annál gyakrabban találkozhatunk [...] az erdélyi unitáriusok katalógusait forgatva." Másrészt - szintén mellőzve az alaposabb vizsgálatot - azzal magyarázza a vizsgált szerző Palingenius-ismeretét, hogy „Laczkovics először talán barátjának, Trencknek Mérôserpenyő címü antiklerikális írásában találkozhatott Palingenius nevével," mivel mindketten ugyanazt a sorpárt

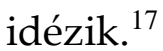

A példa jelzi a Palingeniusra irányuló magyarországi figyelem egyenetlenségét, esetlegességét ${ }^{18}$ - annak ellenére, hogy a Zodiacus vitae hazai ismerete a 16. század második felétől folyamatosan, a legkülönfélébb szinteken adatolható. Mindez arra ösztönzött, hogy megkíséreljem feltárni a mű magyarországi befogadástörténetének fő vonalait. ${ }^{19} \mathrm{~A} Z \mathrm{Zo}$ diacus vitaenek nem ismert teljes terjedelmü magyarországi nyomtatott kiadása. Ugyanakkor a mü különféle kiadásaiból jelentős számú példány jutott el Magyarországra. Beszerzése, birtoklása és használata a 16. század második felétől folyamatosnak tekinthető.

Ezek után aligha meglepő, hogy a magyar vonatkozású album amicorum bejegyzések között gyakoriak a Zodiacus vitaeből származó sorok, mint jókívánságok és bölcs tanácsok. Így például Johannes Coccejus 1617-1637 közötti bejegyzéseket tartalmazó, a brémai egyetemi

16 BALÁZs (2008: 61-70, itt: 68-69).

${ }^{17}$ Laczkovics Trenck Bilanz [...] (1790) címü munkáján kívül nagyon sok helyről meríthette Palingenius-ismeretét.

18 Így például egy elsietett megállapítás szerint Palingenius Zodiacus vitaeje „reneszánsz közhelyek aranybányája". OLÁH (2016: 67-68).

${ }^{19}$ A teljes terjedelmü tanulmány vizsgálja a Zodiacus vitae jelenlétét a történeti könyvtárakban, a régi magyar irodalomban és hosszasan foglalkozik magyarországi fordításaival. 
könyvtárban található album amicorumában a hetvennégy személytől, köztük hét magyartól származó inscriptiók forrásai között feltünik Palingenius neve is. A Debrecenben végzett, majd külföldi peregrinációja után néhány évig ugyanitt oktató Szentpéteri P. Antal 1624. június 14-én készített inscriptiót Brémában Coccejus albumába, két hexametert idézve a Zodiacus vitaeből: Virtutem veram qui possidet ille quietus, / Ille satis felix permittat caetera divis. ${ }^{20} \mathrm{Ez}$ a szövegrész pontos idézet a VI. (Virgo) liberből (664-665. sor), s feltételezhető, hogy a bejegyző olvasta a hivatkozott müvet.

Ezt a bejegyzést azért emeltem ki, mert hiányzik a hungarica jellegü 16-18. századi album amicorum bejegyzések Szegeden készült, Inscriptiones Alborum Amicorum (= IAA) címü adatbázisából. Az adatbázis célkitüzése szerint a teljesség igényével tartalmazza a magyarországi származású albumtulajdonosok emlékkönyveinek bejegyzéseit, a nem magyarországi származású tulajdonosok emlékverseinek magyarországi bejegyzőktől származó inscriptióit, az ezekkel azonos oldalon található egyéb bejegyzéseket, a Magyarországon kelt, valamint az országot és a magyarországiakat érintő bejegyzéseket. Az adatbázis indexe ${ }^{21}$ alapján összesen harmincöt inscriptio forrása Palingenius, ami előkelő gyakoriságot jelent a tíz fölötti hivatkozással rendelkező szerzők körében. Összevetésként: ugyanitt Kálvin János hét, Bacon és Szent Ambrus tizenöt-tizenöt, Andrea Alciato tizenhat, Comenius tizenkilenc, Arisztotelész húsz, Ausonius huszonegy idézettel szerepel; a Palingeniustól való idézeteket meghaladó számú inscriptiók például Clairvaux-i Szent Bernáttól (49), Luther Mártontól (60) és Szent Ágostontól (131) származnak.

$\mathrm{Az}$ adatbázis Palingenius-idézeteit az időrendet követő táblázatba rendeztem, hogy lehetővé váljon a szövegrészek áttekintése, a bejegyzők, az albumtulajdonosok, a bejegyzési helyek és idők elemzése (Függelék, 2. táblázat). Az 1610-1797 között keletkezett harmincöt bejegyzés közül kettő valójában nem a Zodiacus vitaeből származik. ${ }^{22}$ Az egyik - az egyetlen német nyelvü - inscriptio (1780. 07. 18.) Charles Bonnet (17201793) francia származású genfi filozófiai író La Palingénésie philosophique

\footnotetext{
20 GÖMÖRI (1999: 168-176, itt: 173).

${ }^{21}$ Az adatbázist 2017 februárjában használtam.

22 A tévedés ellenére mindkét bejegyzést felvettem a táblázatba.
} 
című munkájának Johann Caspar Lavater által készített, Philosophische Untersuchung (Zürich, 1769) című német fordításának előszavából származik. Mivel a bejegyző, Mikszáth (Mixadt) Dániel a „Bonnet in der Vor. zu sein Paling." forrásmegjelöléssel hivatkozott, az adatbázis szerkesztői - az ellenőrzést elmulasztva - tévesen értelmezték a forrást. Mikszáth a fordítás második, Philosophische Palingenesie (Zürich, 1770) címen megjelent kiadását olvashatta, mely cím-elemként „használta fel” az eredeti címben szereplő görög eredetű kifejezést. ${ }^{23} \mathrm{Az}$ idézet egyébként pontatlan; a bejegyzés valószínűleg emlékezetből készült. A másik esetben nem az adatbázis szerkesztői, hanem maga a bejegyző nevezte meg tévesen Palingeniust forrásaként. A Mezőberényben 1796. október 1-én Klinovszky Tamás által Karló György emlékkönyvébe feltehetően emlékezetből beírt, személyre szabott inscriptio (Ille loci Parochus fit terque quaterque beatus, I In quo non Abraham, Sem, Cham nec vivit Elias) ösforrása valójában Vergilius Aeneise lehet (1,94: o terque quaterque beati). A tévedés - a pontatlanság ellenére - bizonyítja a Zodiacus vitae közkedveltségét és divatosságát. Mindezt figyelembe véve a továbbiakban harminchárom inscriptióval foglalkozom.

Áttekintve az inscriptiók időbeli megoszlását, a harminchárom bejegyzésből hat a 17., huszonhét a 18. században készült. Az egyes liberek és sorok használatának gyakorisága a bejegyzésekben a következő.

\section{1. táblázat A Zodiacus vitae-inscriptiók időbeli megoszlása}

Liber
I. Aries 8-9
I. Aries 8-9
I. Aries 8-9
I. Aries 104
I. Aries 8-9
II. Taurus 346-349
II. Taurus 365-369
II. Taurus 303-305
II. Taurus 346
II. Taurus 366-369
III. Gemini

17. század

1616. II. 26.

1665. VII. 12.
18. század

1772. IV. 11.

1784. X. 16.

1787. IX. 30.

1744. VIII. 12.

1752. VI. 18.

1778. V. 30.

1781. VIII. 9.

${ }^{23}$ Az IAA indexe (6836) tévesen vette fel a bejegyzés forrásaként Palingeniust. 


\begin{tabular}{|c|c|c|}
\hline III. Gemini 82-85 & & 1755. II. 6. \\
\hline III. Gemini 176-177, 170-173, 164-163 & & 1768. I. 5. \\
\hline IV. Cancer 40-43 & 1648-1656 között & \\
\hline IV. Cancer 144-145, 147-148 & 1692. V. 19. & \\
\hline IV. Cancer 505-508 & & 1757. IV. 7. \\
\hline IV. Cancer 277-278 & & 1770. X. 11. \\
\hline IV. Cancer 277 & & 1796. IX. 26. \\
\hline IV. Cancer 796-799 & & 1797. VII. 21. \\
\hline V. Leo & 0 & \\
\hline V. Leo 906-907 & & 1779. VI. 5. \\
\hline V. Leo 794-797 & & 1785. VII. 20. \\
\hline VI. Virgo 346 & 1610. II. 8. & \\
\hline VI. Virgo 584-585 & & 1762. VI. 24. \\
\hline VI. Virgo 197-202 & & 1783. III. 23. \\
\hline VII. Libra & 0 & \\
\hline VII. Libra 648-650 & & 1752-1756 között \\
\hline VIII. Scorpio & 0 & \\
\hline VIII. Scorpio 975-977 & & 1761. IX. 1. \\
\hline IX. Sagittarius & 0 & \\
\hline IX. Sagittarius 772,774-778 & & 1760. III. 13. \\
\hline IX. Sagittarius 970,973 & & 1779. VII. 3. \\
\hline IX. Sagittarius 812-814 & & 1783. II. 27. \\
\hline X. Capricornus & 0 & \\
\hline X. Capricornus 120-123 & & 1742. I. 24. \\
\hline X. Capricornus 122-123 & & 1761-1762 között \\
\hline X. Capricornus 720-730, 734-736 & & 1778. V. 29. \\
\hline X. Capricornus 122-123 & & 1789. IV. 16. \\
\hline XI. Aquarius & 0 & \\
\hline XI. Aquarius 516 & & 1791. VI. 13. \\
\hline XII. Pisces & 0 & 0 \\
\hline
\end{tabular}

A táblázat szerint mindössze az utolsó, (XII.) Pisces címü liberből nem választottak inscriptiót, s a legkedveltebb - két 17. századi és négy 18 . századi bejegyzéssel - a Cancer (IV. liber) volt. Ezt követi gyakoriságban az első (Aries) és a második (Taurus) liber öt-öt, majd négy hivatkozással a Capricornus (X.). Ezekből az adatokból az albumok esetleges fennmaradása miatt nehéz valamiféle törvényszerüségre következtetni, annyi azonban érzékelhető, hogy az utolsó liberből, mely a teremtőről és a teremtés megismeréséről szól, s a mü emelkedett befejezése, nem választottak részletet. Annál kedveltebb volt mindkét évszázadban a Venusról értekező IV., a bevezető (I.) és a földi gazdagság leírását, illetve kritikáját 
tartalmazó II. liber. A 18. században (1742-1789 között) ezekhez társult a bölcs emberről szóló X. könyv (Capricornus). Mindez valószínüleg összhangban áll a bejegyzők és az albumok tulajdonosainak középiskolai szintet meghaladó müveltségével, intellektuális igényével, s nem független a különféle európai gnómagyüjtemények Palingeniusidézeteitől sem.

A bejegyzések szövegét megvizsgálva jeleztem a táblázatban a pontos és pontatlan idézeteket, s az utóbbiakat kiegészítettem a helyes szövegrészekkel. A hat 17. századi adatból mindössze egy bizonyult hibátlannak. A 17. század első felében jelenik meg először az egyetlen, a továbbiakban még háromszor ismétlődő inscriptio (ZV I, 8-9) is, mely felhívja a figyelmet a részlet folyamatos kedveltségére. A 18. századi idézetekből ennél sokkal több, tizenhat (59\%) tekinthető pontosnak.

Az idézetek mozaikként történő, egyénivé alakított összeszerkesztésének szokása a 17. század végétől adatolható. Dubovszky Márton korponai rektor két, egymáshoz közeli szövegrészből, egy sor kihagyásával szerkesztette meg Mittuch Ádámnak szóló bejegyzését 1692 májusában (ZV IV, 144-145, 147-148). Ez a szövegalkotási technika a 18. századi inscriptiókban gyakoribbá vált. Kassán például 1768 januárjában az orvostudományt tanuló Fuker J. három közeli, szinte teljesen pontosan idézett szövegrészletből készített bejegyzést Majoros Dánielnek, a teológiai tudományok kandidátusának (ZV III, 176-177, 170-173, 164-163).

A Palingenius-idézetek albumba ,jegyzése” időbeli megoszlásának vizsgálata további feltételes következtetésekre ad lehetőséget. A hat 17. századi bejegyzés közül kettő $(1610,1616)$ a harmincéves háború előtt, négy (1648-56 között, 1665, 1669, 1692) azt követően készült. Míg a 18. század első négy évtizedéből nem ismert albumbeli Zodiacus vitae részlet, az 1741-1797 közötti időből csaknem egyenletesen növekvő eloszlásban huszonhét bejegyzés maradt fenn. ${ }^{24}$ Azaz, a szórványos 17. századi kezdetek után a mü albumban történő felhasználásának divatja a 18. század második felére tehető. E megfigyelést megerősíti az is, hogy mint később részletesen bemutatom - a mü egyetlen ismert, teljes magyar fordítása a jelzett időszak csaknem közepén, 1771-ben készült.

${ }^{24}$ 1741-1750: 2; 1751-1760: 5; 1761-1770: 5; 1771-1780: 5; 1781-1790: 7; 1791-1797: 3. 
A hat 17. századi albumtulajdonos közül kettőnek ismert a tevékenysége: Kaczer Tóbiás lelkész volt, Johann Finck teológiát tanult. Vitnyédy István ügyvéd fiainak albumai szintén tanuló korú ifjaké lehettek. A hat bejegyző egyike, Rakowsky György, vármegyei vicenotariusjuratus, de van közöttük litterarum studiosus (Georg Gottfried Weiss), iskolai rector (Dubowsky Márton) és ismeretes, hogy Hieronymi András a fiatal Thököly Imre nevelője volt. E téren lényeges változás nem történt a 18. században sem. Az albumtulajdonosok többsége evangélikus értelmiségi (Sztehlo, Fabri, Jezowicz, Hrabovszky, Hajnóczy, stb.) vagy unitárius (Pákei) családból származott; többségük a tanulóéveket követően lelkész lett. Jezowicz Pál, Hrabovszky Sámuel wittenbergi diák, Majoros Dániel teológushallgató, Coellnberger Sámuel, Marton István, Bartholomeides Ladislav és Intze B. Sámuel albumába két-két Palingenius idézetet jegyeztek be különböző személyek a 18. század második felében. A 18. századi bejegyzések készítőinek jelentős része szintén az evangélikus felekezethez tartozott, s a teológiát- és orvostudományt tanuló diákok és diáktársak, iskolarektorok, jogi hivatalt viselők, lelkészek között oszlik meg. Eszerint jobbára a közép- vagy felső szintü müveltséget szerzett személyek készítettek bejegyzéseket a hasonló tudással bíró, illetve azt elsajátítani kívánó társaiknak.

A bejegyzések földrajzi megoszlását vizsgálva, a hat 17. századi idézetből két helyszín ismeretlen, míg a négy ismert helyszín kivétel nélkül Észak- és Nyugat-Magyarországon található: Biccse (ma Bytča, Szlovákia), Sopron, Eperjes (ma Prešov, Szlovákia), Korpona (ma Krupina, Szlovákia). A földrajzi helyeket az albumtulajdonosok és a bejegyzők személyével együtt értékelve, jól érzékelhető a személyek evangélikusprotestáns túlsúlya. A huszonhét 18. századi bejegyzés helyszínéből huszonöt ismert, melyek két részre bonthatók: tizenöt bejegyzés hazai településen, 1757-től tíz bejegyzés külföldön készült. Míg a hazai bejegyzéseknél nem ismétlődnek a települések, a külföldiek Jéna (5), Wittenberg (3), Leiden (1) és Kassel (1) között oszlanak meg. Ismeretes, hogy e városok protestáns egyetemein gyakran fordultak meg magyarországi peregrinusok. Az inscriptiók hazai helyszínei közül ÉszakMagyarországot képviseli Hollólomnic (Holumnica, ma Szlovákia), Jolsva (Jelšava, ma Szlovákia), Berzéte (Brzotín, ma Szlovákia), Selmec- 
bánya (Banská Štiavnica, ma Szlovákia), Kassa (Košice, ma Szlovákia), Pozsony (Bratislava, ma Szlovákia), Besztercebánya (Banská Bystrica, ma Szlovákia), Alsószkálnok (Nižý Skálnik, ma Szlovákia), Csécs (Čečejovce, ma Szlovákia), Nagyszalatna (Zvolenská Slatina, ma Szlovákia), Késmárk (ma Szlovákia) és Osgyán (Ožd’any, ma Szlovákia), Nyugat-Magyarországot Sopron, a középső országrészt Péteri és Pest. Ezek az adatok szintén túlnyomórészt protestáns bejegyzőkre, elsősorban diákokra és lelkészekre, valamint ugyanilyen felekezetü albumtulajdonosokra utalnak.

Az album amicorum-bejegyzések a társadalom egy viszonylag szűk, felekezetileg többnyire meghatározott értelmiségi csoportját reprezentálják. Ugyanakkor az inscriptiók szövege nem mutat felekezeti sajátosságokat, s erkölcsi normákkal, a helyes életvitellel és az ember földi boldogulásának összetevőivel foglalkozik. Számbavételükkel jól lemérhető a Zodiacus vitae 17. század elejétól folyamatos, a 18. század második felében kiteljesedett recepciója.

Az IAA adatbázisból származó Palingenius-adatokat először Wolfgang Klose vizsgálati eredményeivel kíséreltem meg összevetni. Mivel Klose a 16. századi, elsősorban német vonatkozású, európai album amicorumokkal foglalkozott és a bejegyzéseknek csupán az összesített adatait közölte, nem nyílt lehetőség tartalmi összevetésre. Klose egyik munkájában az 1574 előtti bejegyzések között 26 Palingenius-adatot említ, ${ }^{25}$ majd egy évvel később ugyanebből az időszakból összesen 22 , illetve 20 bejegyzésre utal. ${ }^{26}$ Ezek a számok önmagukban is felhívják a figyelmet a Zodiacus vitae első kiadását (1531) követő gyors recepcióra az album amicorumokban.

A folyamatosan épülő Repertorium Alborum Amicorum (= RAA) tizedik verziójában (22. 01. 2017 - www.raa.phil.uni-erlangen.de) - mely időbeli korlátozás nélkül 26 országból 783 őrzőhely több mint háromezer album amicorumának mintegy 251000 bejegyzését tartalmazza szintén áttekintettem a Zodiacus vitaeből származó adatokat. Az 15491788 közötti időszakból az RAA jelenleg (2017. 05. 31) összesen negyven Palingenius-bejegyzést tartalmaz. Ezek évszázadonkénti megoszlása a

\footnotetext{
${ }^{25}$ KLOSE (1988: 721).

${ }^{26}$ KLOSE (1989: 13-31, itt: 19-20, 21).
} 
következő: a 16. századból 8, a 17. és a 18. századból egyaránt 16-16 inscriptio található, azaz az arányok jelentősen eltérnek az IAA arányaitól (17. század 6, 18. század 27). A különbség valószínüleg elsősorban a magyar történelem sajátosságaiból, mindenekelőtt a török tartós 16-17. századi jelenlétéből adódik, s jól tükrözi a hazai Palingenius-recepció időbeli eltolódásait.

Feltételeztem, hogy a két adatbázis adatai összevethetők, s választ kaphatunk arra, vannak-e azonos Palingenius-inscriptiók, és milyen ezek ismétlődési gyakorisága - azaz megragadható-e egy-egy inscriptió széles körü kedvelése, divatszerü átvétele. Míg az összevetésre az IAA adatai kivétel nélkül használhatók lennének, az RAA negyven, szövegszerüen közzé nem tett inscriptiójából mindössze három bizonyult összevethetőnek, ${ }^{27}$ mivel a többi harminchét esetben hiányzik a vonatkozó részlet pontos hivatkozása. A három közül egyetlen esetben (RAA, 1549. év: ZV IV,40-45 - IAA, 1648-1656 között: ZV IV,40-43) találtam ismétlődést. Figyelembe véve, hogy a magyarországi album amicorumokban a legtöbbször idézett Zodiacus vitae-könyv éppen a negyedik (Cancer), nem zárható ki a lehetőség, hogy az idézett részletet nem közvetlenül a müből merítették, hanem szállóige-szerüen terjedt, divatos inscriptióként használták. ${ }^{28}$

$* * *$

A vizsgálat jelzi, hogy az eddig lényegében ismeretlen magyarországi Palingenius-recepciót különféle források bevonásával, komplex módon érdemes megközelíteni. A teljes terjedelmü tanulmányban megvizsgált könyv- és könyvtártörténeti dokumentumok több száz év távlatában bizonyítják a Zodiacus vitae folyamatos hazai ismeretét, olvasását és használatát. Humanista tudósok, protestáns, katolikus, egyházi és világi értelmiségiek, főnemesi és polgári személyek, könyvtárak éppúgy beszerezték kiadásait, mint - elsősorban a 18. század második felétől - a középiskolai könyvgyűjtemények. A fennmaradt példányok az elmúlt

\footnotetext{
27 ZV IX,967-969, IV,40-45, II,1.

${ }^{28} \mathrm{Ha}$ az RAA-ban szereplő inscriptiókat szövegszerüen közlik és/vagy pontosítják a forráshivatkozásokat, érdemes lesz ismét elvégezni a vizsgálatot.
} 
generációk általi tartós használat nyomait őrzik. A német fordításokból is több példány eljutott Magyarországra.

A régi magyar irodalom különféle müfajú szövegeiben a 16. század második felétől mutatható ki a Zodiacus vitae-részletek tudatos beemelése. ${ }^{29} \mathrm{Az}$ első magyar nyelvű Palingenius-sor megjelenése előtt Kovacsóczy Farkas, Johannes Bocatius és Miskolczi Csulyak István képviseli az aktív recepciót. Jelenlegi tudásom szerint az első magyarra lefordított Zodiacus vitae-sorok Pataki Füsüs János Királyoknak tüköre (Bártfa 1626) című erkölcstani munkájában olvashatók. A magyarul megszólaló „Palingenius"-t néhány évvel megelőzte a mü részleteinek felekezeti szellemben átfunkcionalizált, eleinte fordítás nélküli felhasználása a hitvitairodalomban. Ez a folyamat 1614-től kezdődött. A célzatosan kiválasztott sorok ideológiai-eszmei célzatú alkalmazásának újabb, látványos időszaka a 18. század vége.

A Zodiacus vitae iskolai használatára - Miskolczi Csulyak 1600-ban Sárospatakon előadott diákversét követően - a Lorántffy Zsuzsanna által támogatott váradi református kollégiumból származik az első forrás, az 1605-1657 közötti időszakból. Ennél pontosabban ma még nem datálható a Szentkirályi Mihály váradi orator tanuló által készített Aglaiapoéma, mely egy nagyrészt Palingenius múvéből kiemelt és aktualizált hexameterekből álló vendég-szöveg. Ugyanezt a munkát a sárospataki iskolában is felhasználták. Több adat utal a mü tananyagszerü használatára a latin nyelv és a poézis gyakorlati oktatásában egészen a 19. század első feléig.

A mű ma ismert egyetlen, teljes terjedelmü verses fordítása nemzetközi összehasonlításban meglehetősen későn, 1771-ben készült. ${ }^{30}$ A fordítást kéziratos másolatok tették ismertté, egyik példányát Széchényi Ferenc vásárolta meg nyolc aranyért. ${ }^{31}$ A szöveg "szabad" fordítása (,kohollása”) Elefánti Jáklin József nagyszombati bíró nevéhez kapcsolódik, aki valószínüleg „szórakozásból”, hasznos időtöltésként készítette azt. Ez a „magyar Palingenius” több mint két évszázaddal később kelet-

\footnotetext{
${ }^{29}$ KNAPP (2018).

30 KNAPP (2017).

${ }^{31}$ Széchényi Ferenc nyomtatott könyvtárkatalógusában a Zodiacus vitae egyetlen kiadása sem szerepel.
} 
kezett, mint Mikołaj Rej lengyel fordítása, ugyanakkor, mint szabad átdolgozás és értelmezés több tekintetben mégis e mellé állítható.

A tanköltemény kedveltségét jelzik a peregrinusok körében az album amicorum-bejegyzések. A hungarica vonatkozású inscriptiók jobbára pontosan idézik a mű gnómaszerüen kiemelt részleteit; az idézetek tudatos, egyénre szabott kombinálása és átfunkcionálása a kor nemzetközi gyakorlatát követi. A recepció 20. századig ívelő történetét Mikszáth Kálmán neve éppúgy jelzi, mint a különféle kiadások előfordulása az iskolai könyvtárakban a II. világháború előtti időszakban.

\section{Felhasznált irodalom}

BACCHELLI 1985a Fr. BACCHELLI, Note per un inquadramento biografico di Marcello Palingenio Stellato, Rinascimento, 2a serie, 25 (1985), 275-292.

BACCHELLi 1985b Fr. BACCHELLI, Palingenio e Postel, Rinascimento, 2a serie, 30 (1985), 309-315.

BACCHELl 1999 Fr. BACCHELLI, Palingenio e la crisi dell'aristotelismo, in: Sciences et religions. De Copernic à Galilée (1540-1610), Actes du Colloque de Rome (12-14. déc. 1996), Rome - Paris, 1999, 357-374.

BALÁZS 2008

BALÁZS P., Laczkovics János 1791-ben írott valláskritikai pamfletjeiröl, ItK, 112 (2008), 61-70.

ChOMArat 1996 J. ChOMARAT (ed.), Palingène (Pier Angelo Manzolli dit Marzello Palingenio Stellato) Le zodiaque de la vie (Zodiacus vitae) XII livres, Texte latin établi, traduit et annoté, Genève, 1996.

De BujANDA 1990 J. M. De Bujanda (ed.), Index de Rome 1557, 1559, 1564: Les premiers index romains et l'index du Concile de Trente, Sherbrooke, 1990.

FACCIOLATI 1765 J. FACCIOLATI, Epistolae Latinae, Patavii, 1765.

GIRALDI 1551

GÖMÖRI 1999

G. G. GIRALDI, Dialogi duo de Poetis nostrorum temporum [...], Florentiae, 1551.

GÖMÖRI GY., A fiatal Coccejus magyar barátai és tanítványai, in: A bujdosó Balassitól a meggyászolt Zrínyi Miklósig: Tanulmányok, Budapest, 1999, 168-176.

Index 1764

Index librorum prohibitorum, Romae, 1764.

Index 1862

Index librorum prohibitorum, Neapoli, 1862.

KLOSE 1988

W. KLOSE, Corpus Alborum Amicorum. Beschreibendes Verzeichnis der Stammbücher des 16. Jahrhunderts, Stuttgart, 1988.

KLOSE 1989 W. KLOSE, Stammbucheintragungen im 16. Jahrhundert im Spiegel kultureller Strömungen, in: W. KLOSE (hrsg.), Stammbücher des 16. Jahrhunderts, Wiesbaden, 1989, 13-31.

KNAPP 2017

KNAPP É., Palingenius Zodiacus vitae-jének magyarországi fordításai, előadás a III. Neolatin Konferencián 2017. XII. 7-9, megjelenés alatt a konferenciakötetben. 
KNAPP 2018

KÜHLMANN 2016

LEPRI 2015

KNAPP É., Palingenius Zodiacus vitae-je a régi magyar irodalomban, ItK, 122 (2018), 127-144.

W. KüHLMANN, Wissen als Poesie, Berlin - Boston, 2016.

V. LEPRI, Hic liber libenter legitur in Polonia: Mapping the popularity of the Zodiacus Vitae in Poland between the sixteenth and seventeenth centuries, Odrodzenie i Reformacja w Polsce, 59 (2015), 67-93.

NAgYSOlyMOSI 1934 NAgYSOlyMOSI J., A lengyel irodalom, Budapest, 1934.

OKOŃ 2014

J. OKOŃ, Kelet és Nyugat határán. Jezsuita humanizmus a 16-17. századi Lengyelországban, in: BÉKÉS E. - SzILÁGYI E. R. (szerk.), Latinitas Polona: A latin nyelv szerepe és jelentösége a történelmi Lengyelország kora újkori irodalmában, Budapest, 2014.

OLÁH 2016

OLÁH R., Miskolci Csulyak István és Tofeus Mihály református lelkészek könyves müveltsége, PhD dolgozat, Debrecen, Irodalomtudományok Doktori Iskola, 2016.

Palumbo 2007 M. Palumbo, Manzoli, Pier Angelo, in: M. Caravale (dir.), Dizionario Biografico degli Italiani, vol. 69 Mangiabotti - Marconi, Roma, 2007, 294-298.

SCALIGER 1607 J. C. SCALIGER, Poetices libri septem, Heidelberg, ${ }^{4} 1607$.

SZÁRAZ 2010 SZÁRAZ O., Bán Imre professzor kéziratos hagyatékának egyszerüsített listája, Debrecen, 2010, kézirat.

\section{Függelék}

\section{2. táblázat: Palingenius-inscriptiók az album amicorumokban az IAA adatbázis alapján (időrendben)}

Alkalmazott jelölések:

[]-ben a javított szöveg a javítandó szó/rész után;

aláhúzás = bővítés;

hivatkozás fettel = pontos a hivatkozás;

dőlt = javítás, a hivatkozás pontosítására IAA-hoz képest.

Megjegyzés:

A központozás, sormetszet eltéréseit nem vettem figyelembe.

A rövidítések feloldása:

BCU = Lucian Blaga Központi Egyetemi Könyvtár, Kolozsvár (Biblioteca

Centrală Universitară „Lucian Blaga”, Cluj-Napoca)

EOL = Evangélikus Országos Levéltár, Budapest

OSzK = Országos Széchényi Könyvtár 


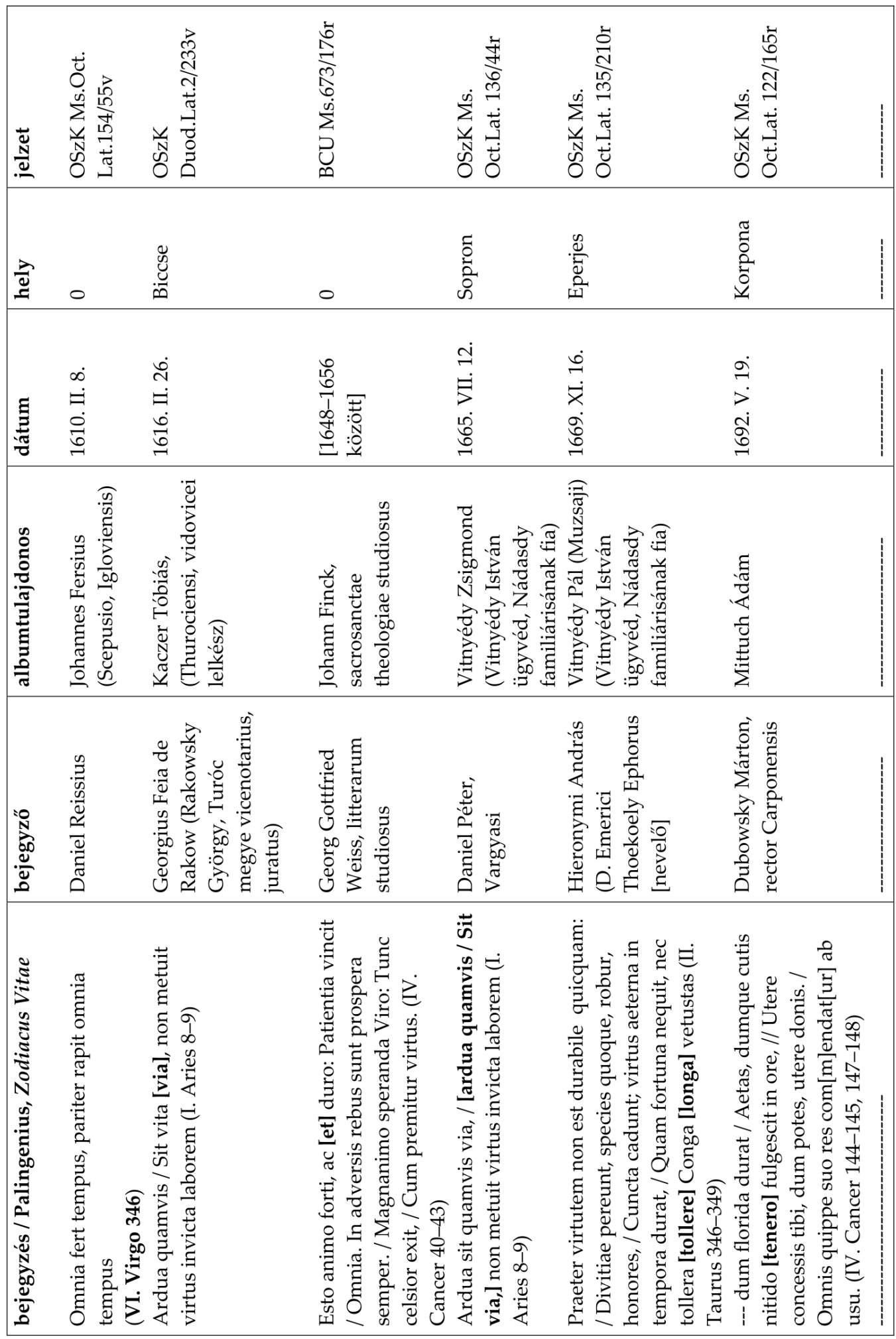




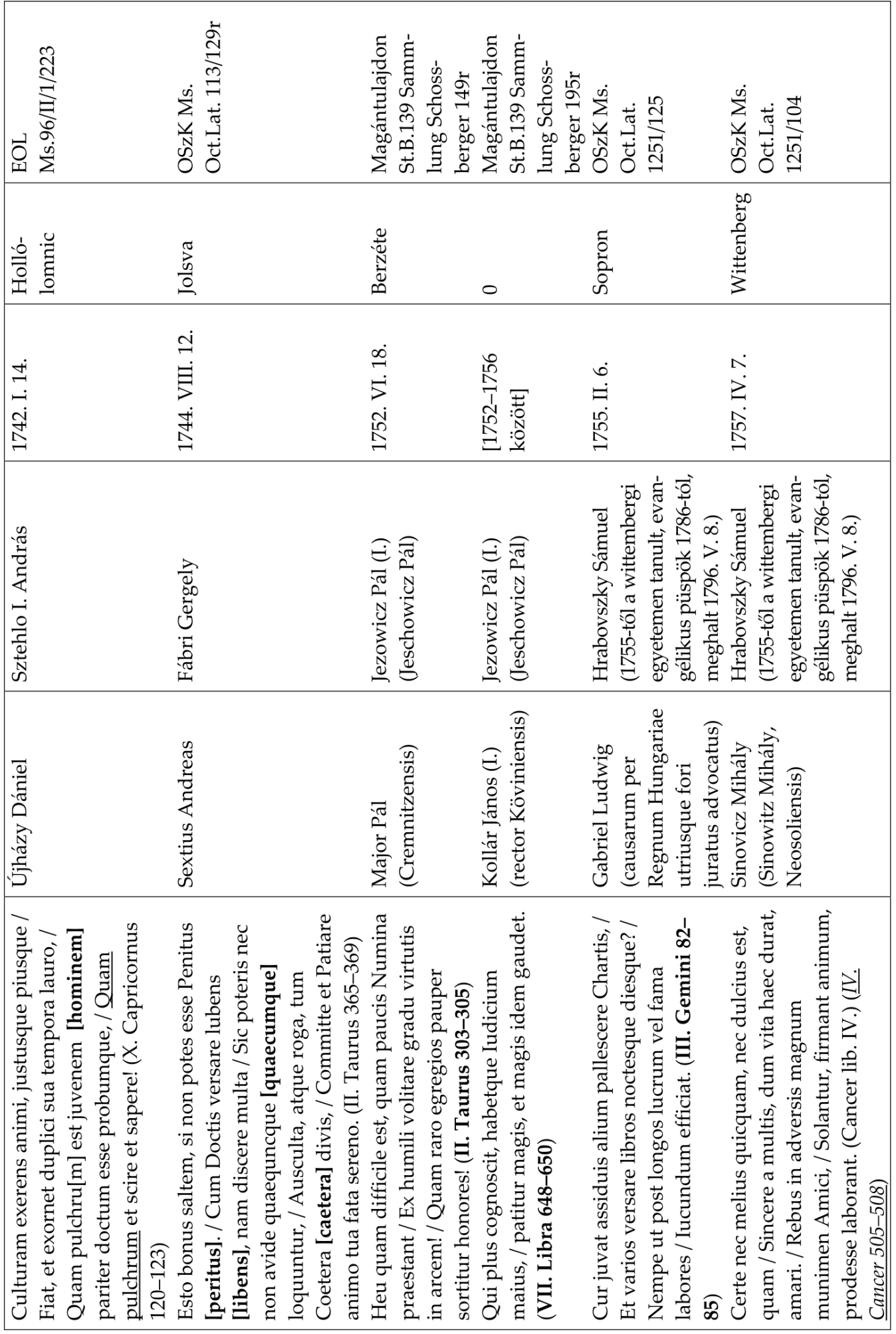




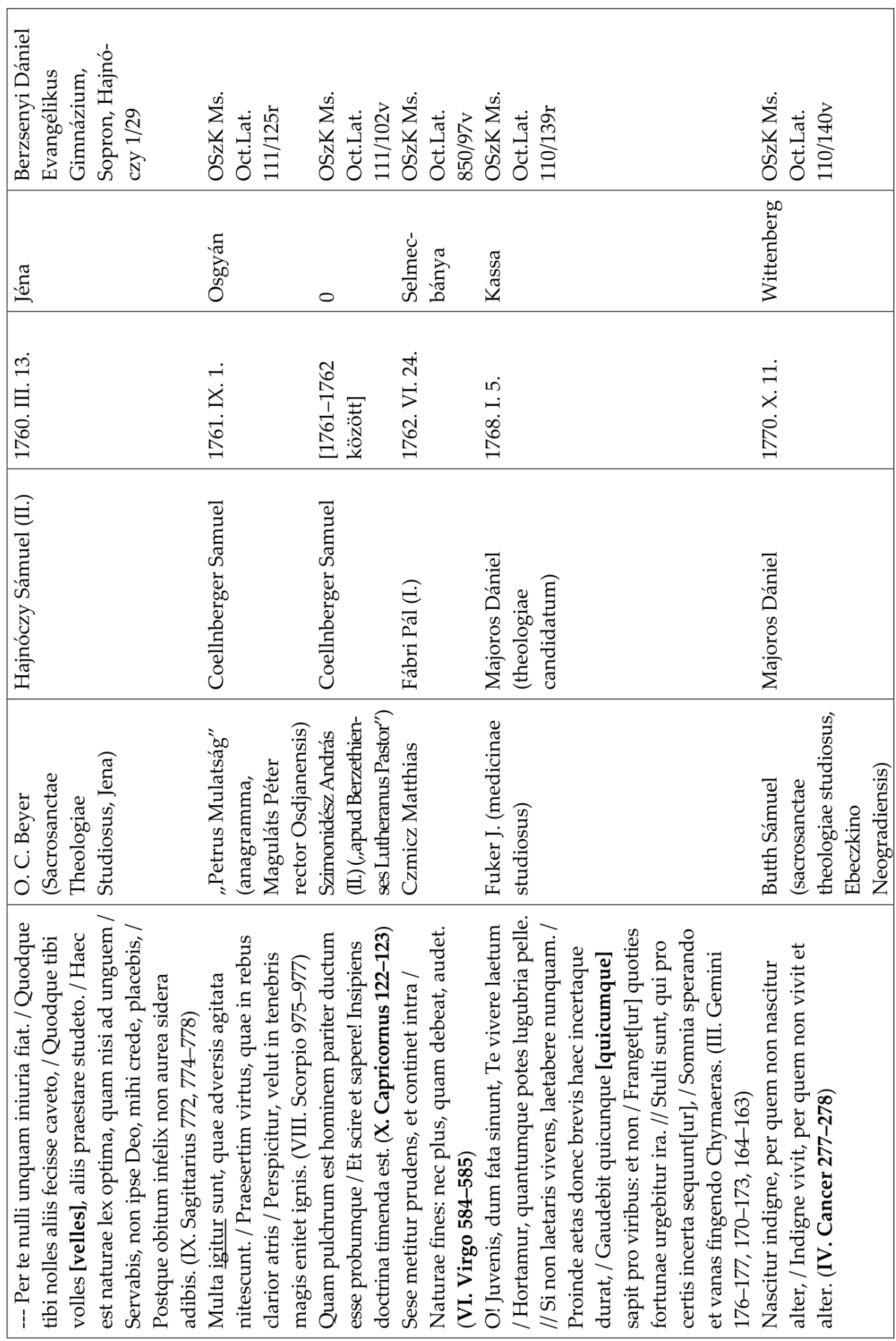




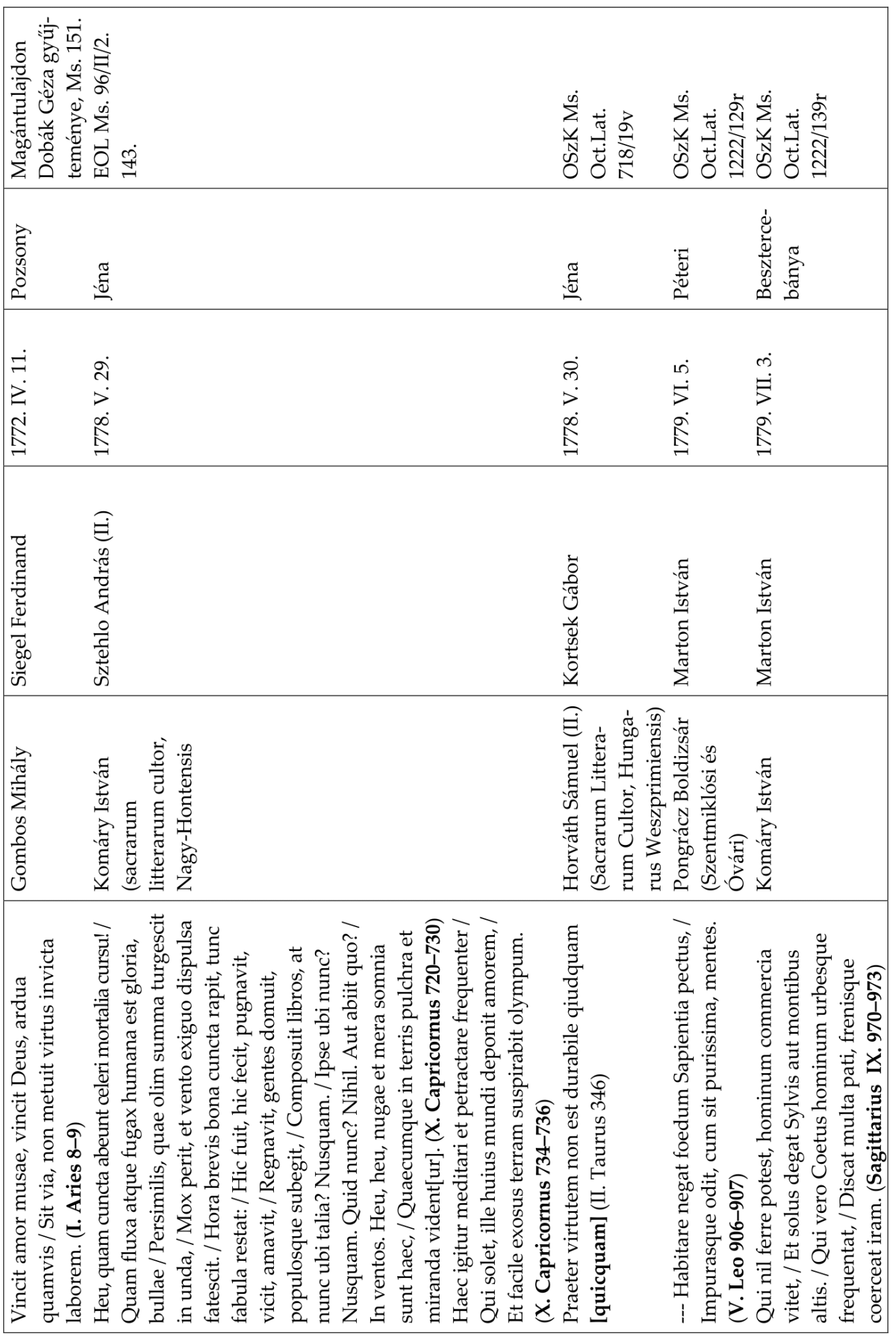




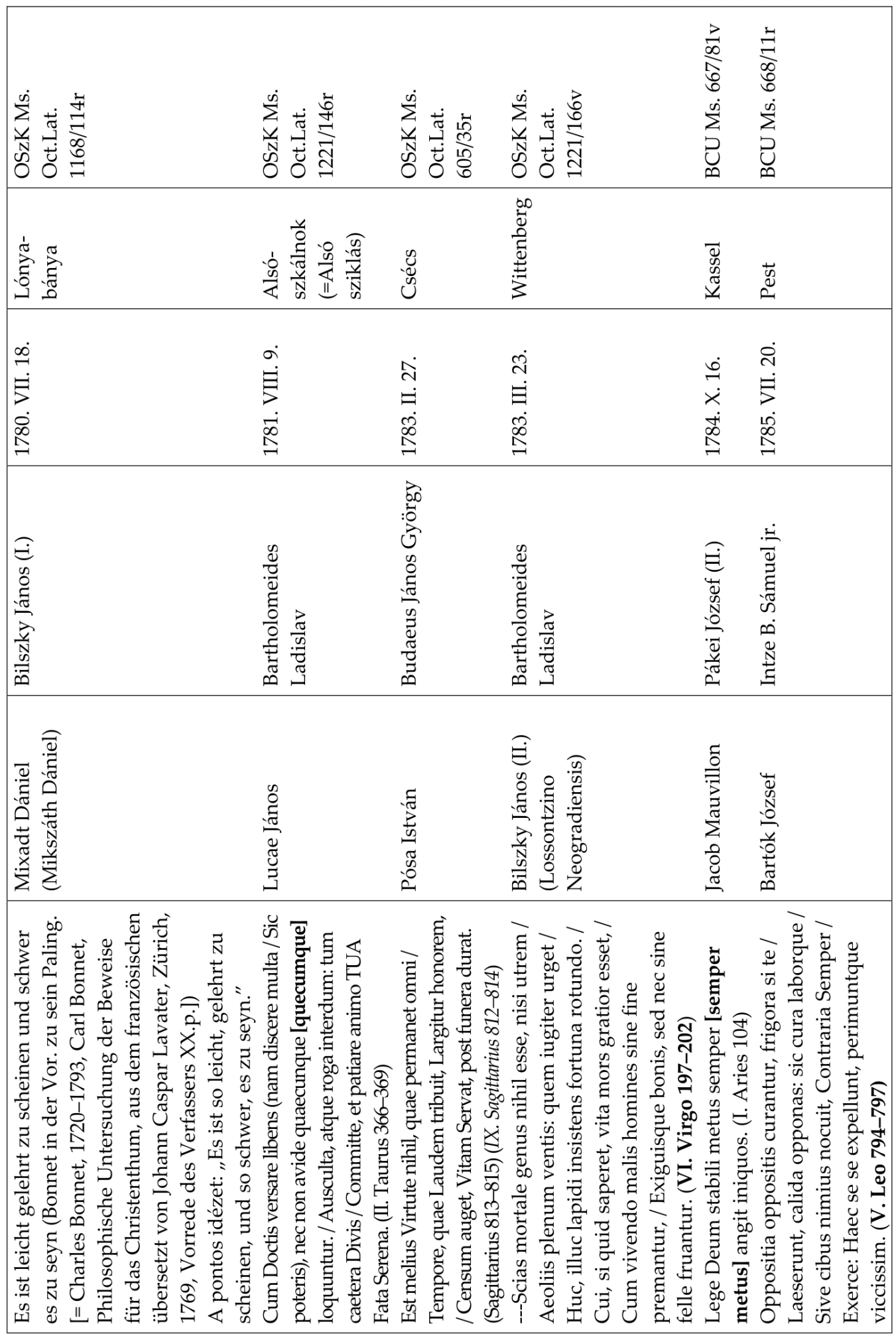




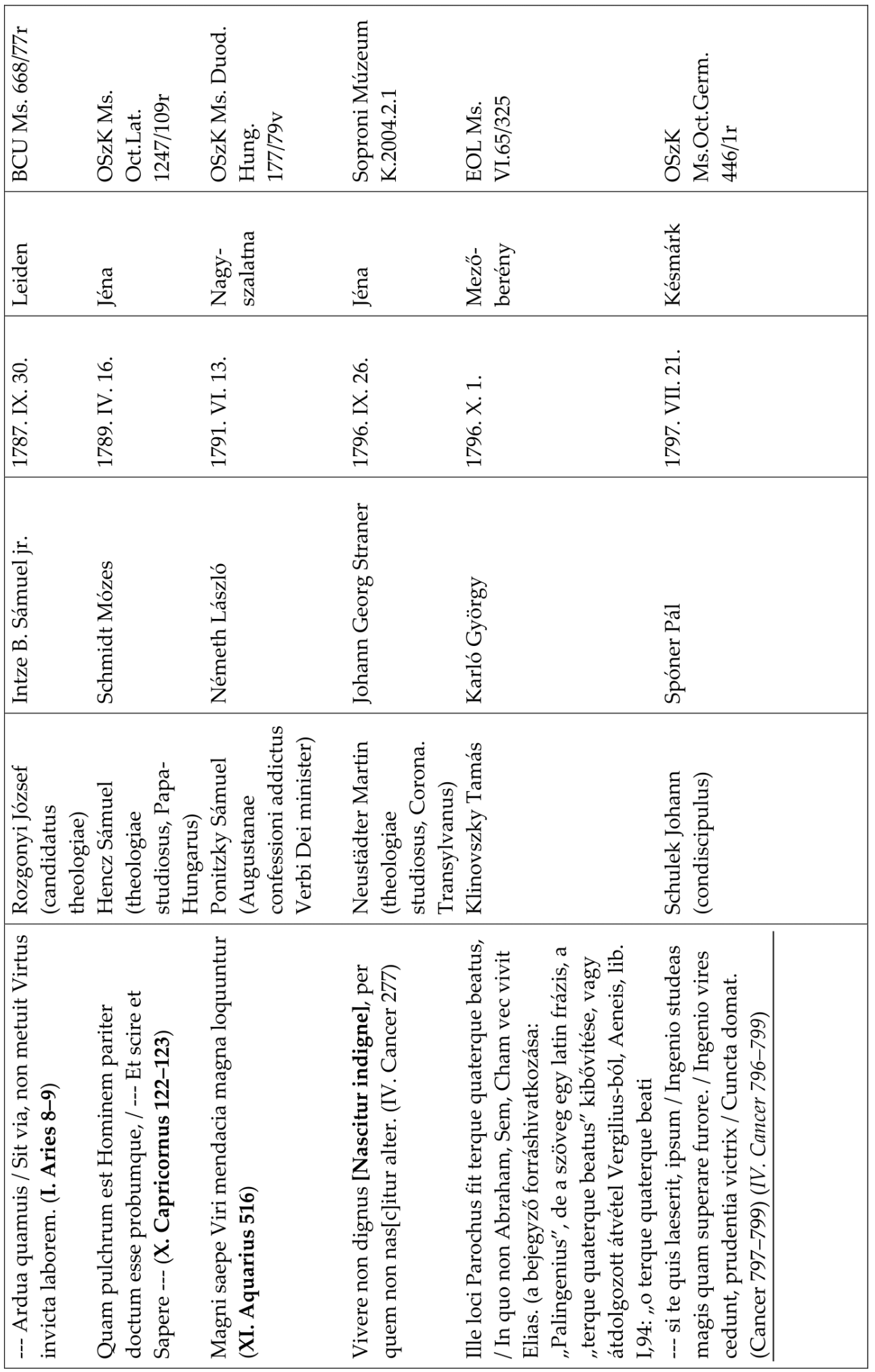

